\title{
Capital Flows and Money Supply: The Degree of Sterilization in Pakistan
}

\author{
Hina Ali ${ }^{1 *}$, Sadia Sajjad ${ }^{1}$
}

\begin{abstract}
The present study proposes to analyze the impact of the capital flows on the economic growth. The change in the capital flows affects the money supply in the economy which in return influences the economic growth. The augmented dickey fuller test (ADF), descriptive Analysis, correlation method, and the auto regressive distribution lag are employed in this work. The ADF test is delved to examine the Stationarity of the variables and the correlation between them. The descriptive analysis is used to check the normality of the variable whether the variables is normally distributed or not. The survey bases on time series data ranging from the year 1974 to 2014. The variables as the gross domestic product (GDP), exchange rate (ER), inflation (INF), consumer price index (CPI), money supply (M2), total reserves (TR) and the foreign direct investment (FDI), price indices (PI). The research findings are Foreign direct investment, Exchange rate, Inflation rate, Consumer Price Index has the positive impact on the GDP while the Private Investment, Total reserves, and Money supply have the negative impact on the GDP. The value of the R square is 0.99874 which is very good. It means that the 99 percent variations exist in dependent variable due to independent variables.
\end{abstract}

Keywords: Capital Flows, Money Supply, Total Reserves, Gross Domestic Product, Pakistan.

\section{Introduction}

Capital flow means the money transfer across the border; it refers to the movement of money for the purpose of investment, trade, or the growth of business or production. The capital means cash and factories, property owned by the owner for the purpose of production. For the purpose of analysis the US government used the aggregated capital flow. The capital flows across the world in the form of flow of bonds, assets in the form of cash. The purpose of capital flow is to increase the growth of economy in the form of investment capital. The strength of the capital flow can be explained with the help of capital flow in the capital market. The trend of capital flows can be used to predict the future investment risk. With the help of capital flow the investor or predictors can find out trend of growth and equilibrium or disequilibria of stock market https://doi.org/10.30537/sijmb.v4i1.102

${ }^{1}$ Department of Economics, Women University Multan Pakistan

*Corresponding Author: hinaali@wum.edu.pk 
in the future investment of capital. The flow of capital can be explained and monitored by the capital market. The capital market is that market which is used to find out the sale and purchase of goods, bonds, assets, and debt in the other markets. The capital market can be used to monitor the investment activities which are done with the help of capital flows across the world market. It can also judge investment and saving activities between the sellers of capital and the buyers of the capital. There are two type of capital markets in the world that is primary and secondary capital market. The primary capital market is including the flows of liquid assets such as bonds, equity, while the secondary capital market is involved in the trade activities in the world market. In the primary capital market the companies issue bonds and other stock assets to the investors while these secondary capital markets include in the investment such as the capital from the pension funds, mutual funds and the funds in the bank and financial institution. Other type of capital flow is in the form of the government bonds issued by the government for the sake of monetary expansion and increase the supply of money in order to remove the financial crisis. There are direct relationships between the capital market and the size of economy. The capital market directly and indirectly depends on the size of the economy. As the size of economy is larger than the capital market also be greater and vice versa. United States the world largest economy has largest and deepest capital market. When the capital flow is increased it leads to increase the high exchange rate with lower rick while the capital users try to increase the capital with the lowest cost. Money supply means the total amount of the money asset is available in the country. Due to the larger outflow of capital cause the financial deficit such as in the 1980 international crisis, in 1992-93 crisis in European exchange rate mechanism, 1994-1995 Mexican peso crisis and 1997-1998 Asian crises. Hot money is the speculative capital flow that mainly is used in short term to fulfil the financial needs. The hot money is used to remove the boom period of the one sector of the economy. When one part of the economy is suffering from the financial crisis and budget deficit then this situation leads to boom period. In this situation the investors are not ready to invest their capital assets in that sector of economy because they want a better destination for their capital assets so they do not transfer their assets in that part. In this case the hot money is used to remove the financial crisis and boom period of that part of the economy. When the capital flow is out of the pains then this situation causes the financial crisis.

The capital flow can increase the growth of economy and enables the household to be achieving the highest consumption level during different time periods. The capital flow helps the countries to achieve the highest possible level of the portfolio. Qayyum and Khan (2003), Analyzed the money supply and capital flow and the degree of sterilization in Pakistan by using the time series data that is quarterly data and concluded that degree of sterilization and the exchange rate are directly related and the sterilization decreases the impact of exchange rate on the price indices. Ullah, Haider, and Azim (2012), explained the exchange market forces on the Pakistan rupees exchange rate in the globalization period by using the time series data which is

Sukkur IBA Journal of Management and Business | Volume 4 No. 1 January - June 2017 @ Sukkur IBA University 
quarterly data and using the co integration techniques. They concluded that the relationships between the exchange rate and capital flow and money supply are very strong. Fry-McKibbin and Wanaguru (2013), analyzed the monopoly of capital flow by using the time series data and techniques of ADF and OLS to prove the Stationarity of the variables. This paper concluded that there is strong relationship between the interest rate and capital flow. Lagner and Knyphausen-Aufseß (2012), investigated the practical approach towards the capital and money market. This paper explains the relationship between the money market and capital market. There are many literatures that can explain the relationship between the exchange rate, capital flow and the money supply. As Change in the flow of capital can affect the exchange rate and the money supply in Pakistan. When the large amount of the capital inflow situation occurs in the country, it has many negative effects. These negative effects increase the inflationary pressure, expansion of monetary policy and decrease in the price of goods in the receiving countries and increase the exchange rate then it causes to be expensive exports as compared to the other countries goods and services. Then in return a situation occurs where too much money chases too few goods. When the large amount of the capital outflow occurred then it caused the price of the goods lower an actual and the value of currency of a country reduced.

The objectives of this study are as below;

[1]. 1: To analyze the impact of the money supply on the GDP.

[2]. 2: To analyze the impact of inflation on GDP.

[3]. 3: To analyze the impact of TR ON GDP.

This evident explained the relationship between the exchange rate, inflation and the money supply in the long run and the short term.

\section{Literature review}

Kaufman, Mote, and Rosenblum (1984), investigated on the effects of sterilization intervention. The main objective of this paper was to explain the capital flows across the world market and the monetary policy and the effect of sterilization. This paper used the time series data ranging from the 1973 to 1980 in order to find capital mobility in US economy. This paper used the two stages two OLS techniques, auto regression model, and ADF test as methodology. This paper used the variables as interest rate, direct portfolio investment, GDP, investment, saving, and inflation gap. The 2S-OLS was consistent under null hypothesis of perfect substitutability and inconsistent under portfolio balance effect. Auto regression component was assumed to arise from structural error. This paper concluded that the portfolio remains insignificant. The portfolio balance remains recognized that typically sterilized intervention operation was very small to existing stock of outside assets. This paper explained that the small intervention may have large general equilibrium effect, sterilized intervention operation was typically so small relative to total assists one reluctant to believe that they have any significance macro-economic impact through portfolio balance channel.

Sukkur IBA Journal of Management and Business | Volume 4 No. 1 January - June 2017 @ Sukkur IBA University 
The portfolio balance model was predicted that uncovered interest rate differential on assets denominated in currency should be increasing function of supply.

Obstfeld (1998), investigated capital flow market world. This paper presented some new empirical approach on the extent of capital market world. The main objective of this paper was to explain the capital flow and impact of capital flows in the market world. This paper used the time series data ranging from the 1960 to 1984. This paper used the correlation techniques to look at the level of Stationarity and non-Stationarity of the variables and the level of significance between the variables. The saving investment correlation coefficient was a structural parameter reflecting the response of domestic investment to shift national saving. This paper conclude that was small size of average current account over a long period was evidence that sizeable barriers impede the free international movement of capital. This paper used the variables as GDP, CPI, investment, consumption, saving, inflation, interest rate, capital consumption and current account balance. This paper concluded international market exchange rate liberalization of industrial country capital market begins. This paper explained that in US and JAPAN the consumptions have behaved as if residents of two countries had across to some risk free borrowing and denting opportunities. Significance level of test statistics were all extremely high for period. This paper reported time series estimation for several countries of correlation between quarter to quarter changes in saving and investment correlation as un-ambiguous evidence about capital mobility. This paper also concluded that capital was essential immobile in some long run sense. The change in saving and change in investment were significance at first difference. Correlation coefficient between the change in saving and change in investment were positively related and statistically insignificant.

Ocampo (2003), investigated monetary policy and financial stability. The main objective of this research paper was to explain the monetary policy and uncertainty and the adopting monetary policies to effect the economy. The purpose of this paper was to evolution of economic environment with the help of a few indicators of economic performance and policy regimes. The indicators of economic performance include an inflation, short term output level, assets price booms and busts. The financial liberalization can be remarkable development in financial sphere. This paper used the time series data ranging from the 1960 to 2002 in order to explain effective decline in prices. This paper used the regression technology as the methodology. This test used to find out correlation and associations between the variables. This paper used the variables as the GDP, GDP deflator, inflation gap, credit gap, output gap, credit assets price, and exchange rate. The basic thesis of this paper was that edging towards the goals of securing simultaneous monetary and financial stability calls for same modifications in the monetary policy both in financial and monetary spheres. This paper indicated that a financial imbalance was a leading cause of inflation. Financial imbalance was build up when the inflation was low and stable. There was a negative relationship between inflation and financial imbalances.

Sukkur IBA Journal of Management and Business | Volume 4 No. 1 January - June 2017 @ Sukkur IBA University 
Bordo and Filardo (2005), investigated capital flows and fiscal discretion and exchange rate policy. This paper used to explain a capital flow model and was linked to exchange rate regime because of endogenous fiscal policy. The main objective of this paper was to explain that hard peg was undesirable in the absence of commitment in fiscal policy. The fiscal authority's subsidies capital flows in order to fix an exchange rate credibility. The monetary authorities follow a rule flexible exchange rate rule in which capital inflows lead to exchange rate appreciation. When the fiscal policy was financed by monetary policy rather than that of the monetary creation rather direct taxation then fixed exchange rate rule may cause both over borrowing and subsequent exchange rate crisis. This paper used the time series data ranging from 1971 to 1999. This paper used the correlation techniques as a methodology. This test used to explain the correlation between the variables and check the stationary of variables. This paper concluded that linkage between fixed exchange rate regimes and capital flows in environment of endogenous fiscal policy. This paper explained that the capital market depends upon the exchange rate policy. The essential conclusion of this paper was that hard peg should be accompanied by coordination between monetary and fiscal policy. This also suggested that an appropriate exchange rate allowing capital inflows to be measured by appreciation. This paper also concluded that level of nominal exchange rate depends on the extent of money supply which depends on limits on direct taxation.

Hyder and Mahboob (2006), investigated the impact of exchange market forces on Pakistan rupees exchange rate during the globalization period. This paper used the methodology of co-integration techniques, dickey-fuller test and descriptive statistics. These techniques were used to explain the stationary and non-stationary between the variables coefficients. This paper used the time series data ranging from the 1965 to1971. The variables in this study were domestic credit growth of the foreign exchange rate, nominal domestic money balance, domestic price, real income, nominal interest rate. This study concluded that the development expectation had statistically and economically significant explanatory power in addition to the behavior of the fundamentals of the Pakistan economy. This paper analyzed the impact of exchange market forces on Pakistan rupees verses dollar exchange rate. The result of this study explained the relationship between the capital flows and the exchange rate. There was a strong association between the exchange rate and capital flows.

Alberola and Serena (2007), investigated the global financed integration monetary policy and reserve accumulation; assessing the limits in emerging economics. Sterilization was implemented through the market instrument open market instrument and to less extent to the fiscal policy managements. There was a strong relationship between the market currency and reserves. High supply currency caused inflation in country. Sterilization through the market operations caused a high interest rate when the supply of assets was higher than that of the demand for assets. Both increased in debt and interest rate caused a potential risk in debt managements. The benchmark model was used by this paper. These techniques used to determine the correlations

Sukkur IBA Journal of Management and Business | Volume 4 No. 1 January - June 2017 @ Sukkur IBA University 
between the coefficients in order to explain the relationship between the capital flows and monetary policy. This study used the time series data ranging from the 1990 to 2005. In this study the variables credit to banking system, foreign exchange reserves, other domestic assets, current account balance, money supply and GDP were used. The central bank can decide to sterilize the reserves accumulation to prevent it from filling into high liquidity in system. Sterilization can be done through market instruments, the central bank is able to contain the monetary cost of reserves accumulation through sterilization and without resorting to change in policy.

Khan (2008), investigated long run and short run Dynamics of foreign reserves and domestic credit. This study formulated and examined the money approach to balance of payment by incorporating the currency substitution version of money demand function by Pakistan. This study used the methodology of FM-OLS and Johansenjealous co integration techniques. This study used the time series data ranging from 1962 to 2005. In this study the variables real output, real exchange rate, domestic credit, foreign reserves. Monetary authorities sterilize foreign exchange reserves to domestic credit by $12 \%$ in long run and $34 \%$ in short run. They concluded that the validity of monetary approach to balance of payment and effectiveness of monetary policy depend upon nature of money function. As the specification of money function has undergone a change the monetary approach has also altered.

Farhi, Gourinchas, and Rey (2011), investigated that the international reserves spar inflation. The main objective of this study was to explain the relationship between the capital flow and the national reserves. This study used the time series data ranging from 1970 to 2006. This study used the methodology of granger cause inflation to check the rate of inflation. In this study the variables nominal income, money supply, real income, velocity of income was used. Global reserves growth significantly raised the inflation rate with lag of two years. The degree of sterilization of the effects of reserves changes on monetary base was changed considerably over time. Central bank international reserves holding have increased significantly in recent years. This paper assesses the consequences for monetary policy both on the theoretical and empirical ground. This paper is especially likely for those countries that operate under fixed exchange but may also affect countries with floating rate proportionate their individual's rate of reserves accumulation. The capital account referred to as the convertibility to the foreign reserved to the country residential. This research paper was to explain the relationship between the world inflation rate and world exchange rate.

Rashid and Husain (2013), examined the capital flow, inflation, and exchange rate volatility. The main objective of this paper was used to investigate the relationship between the capital flows, exchange rate and the inflation in economy. This paper used the linear and nonlinear co integration and GRANGER Causality test were applied in a bi variety as well as multivariate. In this study the variables capital inflow, money

Sukkur IBA Journal of Management and Business | Volume 4 No. 1 January - June 2017 @ Sukkur IBA University 
supply, inflationary pressure, exchange rate, monetary expansion was used. This paper used the time series data ranging from the 1990 to 2007. This paper investigated inflationary effects of capital flows using monthly data. Positive and significant effects of capital inflows on monetary expansion, particularly during the period of massive capital inflows from 2001 to 7 , capital account convertibility referred to the availability of foreign exchange reserves to country residuals to purchase assets abroad are to nonresiduals to purchased assets in the country. Main objective of capital flow was to delay a fall in international reserves. International reserves were a part of monetary base.

Hashmi, Xu, Khan, Bashir, and Ghazanfar (2011), investigated the monetary policy reaction function and sterilization of capital inflows. This paper used the multivariate co integration model. OLS estimation techniques were used by this study to estimate the long run adjustment coefficient of variables. These test used to check the stationary of variables to get the reliable estimate. The co-integration techniques and ADF test were used to check the stationary of the variables and the level of significance between the coefficients. This study focused on estimates of monetary policy reaction function and degree of sterilization for the sample comprising the Pakistan, Korea, Philippine, and Japan by using the time series data ranging from 1980 to 2008. In this study the variables domestic interest rate, real interest rate, real income, money supply, and money demand were used. Over the period of study the central bank concluded a strong sterilization policy but not fully sterilized the capital flow. These countries used the sterilized policy in long run. Short run adjustment to the long run equilibrium shows a high value of adjustment in these countries. The result of this study concluded that there was a strong relationship between the interest rate and inflation. The growth of money supply caused an inflation in Pakistan. Pakistan has sterilized with most of its foreign capital inflows and its coefficient was high in short run and in the long run.

Fry-McKibbin and Wanaguru (2013), examined the Analysis of currency market volatility in Sri Lanka. Objective of this study was to analyze the relationship between the currency market and the inflation in economy. This study used the methodology of latent factor model which is distinguishing between the inventory and non-inventory day .this study used the time series data ranging frome2002 to 2012. In this study the variable les interest rate, inflation, GDP exchange rate and real income were used. The central bank intervention is the foreign exchange market can be distinguish as an effective policy measures which has reduced exchange rate volatility arises in domestic currency markets. This study investigated whether the volatility of currency markets in Sri Lanka stems from domestic currency markets specific sources or external sources. The study explained that the high growth of currency caused the high GDP in economy which caused the high inflation rate in economy.

Demyanyk and Hasan (2010), investigated the foreign exchange stability. This paper examined the relationship between foreign exchange reserves accumulation, exchange rate, inflation and gross domestic product in Nigeria. This study used the methodology

Sukkur IBA Journal of Management and Business | Volume 4 No. 1 January - June 2017 @ Sukkur IBA University 
of ADF test, multivariate co-integration techniques and error correction model. These tests used to investigate the stationery and non-stationery. This study shows the variables in the study have unit root. This study used the time series data ranging from 1980 to 2001 in this study the variable foreign exchange, GDP, inflation, foreign exchange reserves were used. This paper examined the positive relationship between the GDP and exchange rate and significant relationship with the foreign exchange reserves accumulation while inflation has the negatively and insignificant relationship with foreign exchange reserves.

Jegajeevan (2015), examined the simultaneous estimate demand for and supply of money in Austria. This paper used the methodology of simultaneous equation model and applying the three-stage least squares method, ADF and co integration method. This study used the time series data ranging from the 1975 to 2013. In this paper the variables demand for money, supply of money, real income, real interest rate, inflation, output gap and inflation gap were used. The ADF and co-integration test were used to investigate the stationary and non-stationary of variables. This paper concluded that the money demand is negatively related with the interest rate and positively related to the GDP and nominal effective exchange rate and money supply has positive relationship with the interest rate and negatively related with the output gap and inflationary gap .the result of paper suggested that federal reserve's band reduced money supply if the output gap or inflationary gap increased in Australia.

\section{Theoretical and Conceptual Framework \\ 3.1.Quantity theory of Money}

Quantity theory of money is the most important theory about monetary economics which defines the relationship between money and price level just like if there is more money in market available to the consumers so this will also lead to increase in prices of goods and services. The Quantity theory of money was presented by the Classical economists or pre-Keynesian economists. It can be stated as:

$$
\mathbf{P}=\mathbf{f}(\mathbf{M})
$$

$\mathrm{P}$ can be pronounced as price level is fully dependent on money supply. If price level increases with a proportion then money supply will also increase with the same proportion, and if price level decreases then supply of money will also decrease.

The quantity theory of money was first presented in 1586 and it got the great appreciation after another economist named Irving Fisher in 1911. After him many other theories were developed on the same approach. There was also another group of economists that was popular by the name of group Cambridge approach. They were also in favor of the concluded results of Classical economists.

Sukkur IBA Journal of Management and Business | Volume 4 No. 1 January - June 2017 @ Sukkur IBA University 
Assumptions about theory: There are two suppositions about the Quantity theory of money. The first one was generated by the very famous law known as Say's law which is: Supply creates its own demand.

This can be explained as all the goods that are brought in the market are equal to the goods that are brought from the particular market. All we can say that there will be no absence of demand or no single resource will be wasted and every single person in the economy will enjoy full employment.

The second assumption was also driven from the Say's law that is economy is enjoying the condition of full employment.

Quantity theory of money: According to Irving Fisher

As we know that the price level is the determined at the point where demand equals to its supply. Likewise, the merits of money are also decided by the money supply and money demand. In the theory of Irving Fisher, he stressed upon the concept that money is a mean of exchange. It means that money is only used for bargaining purpose. As axiom given here that the total account of goods that are available in the market for the purpose of trade, are equals to the total account of money spending. That can be exampled as:

$$
\text { MV = Epiqi }=\text { PT }
$$

Where:

$\mathrm{M}=$ hand keep money in economy

$\mathrm{V}=$ velocity of circulated money

$\mathrm{P}=$ prices of goods

$\mathrm{EP}=\mathrm{p} 1 \mathrm{q} 1+\mathrm{p} 2 \mathrm{q} 2+\ldots \ldots+$ pnqn are prices $\&$ outputs of goods

qi $=$ quantity of goods to be accomplished

$\mathrm{pi}=$ mean price level

$\mathrm{T}=$ total volume of goods to be traded

This statement has always held true as it tells us about the total accounts of commodity that are available in market for sale and the total expenditures of money to purchase those commodities. The mean number of times when a unit of money moves from one hand to another is known as the velocity of money.

Can be defined as follow:

$$
\mathbf{V}=\mathbf{P x T} / \mathbf{M}
$$

According to Say's law, the velocity of money should be remained fixed because of fully employed economy as it can be found out with the help of use of money in

Sukkur IBA Journal of Management and Business | Volume 4 No. 1 January - June 2017 @ Sukkur IBA University 
payments pattern, environment of banks and transportation costs, changes in population.

If we consider $\mathrm{V} \& \mathrm{~T}$ as constant, then we can also write the above equation as:

$$
\text { MV = PT }
$$

Quantity theory of money: Cambridge approach

Another approach developed by the economists known as Cambridge economists which is known as Cash balance approach.

They argued that money is not only the medium of exchange but also a store of cash or wealth. (Cash that people want to hold for the sake of emergency).

In this approach few of very famous economists were included like Keynes, Marshall, Pigou and Robertson. According to them, people wants to hold money rather the for the purpose of financial transactions also for unwanted circumstances. Thus as an income of single person increases, he/she also increases the demand for cash money to be held. So they represent it as follow:

Where:

$$
\mathbf{M d}=\mathbf{k P Y}
$$

$\mathrm{Y}=$ Aggregate level of output

$\mathrm{P}=$ Level of mean prices

$\mathrm{k}=$ the proportion of income that people wants to hold.

\section{Limitation about Theories:}

Defectiveness in full employment.

$\mathrm{V} \& \mathrm{~T}$ are not being fixed.

This theory is a hypothesis but Fisher's theory is identity.

Aggregates have an effect on price level not money.

So much stress on money supply.

Interest rate is the cause of influence between $\mathrm{M} \& \mathrm{P}$.

After all these shortcoming and demerits, the Quantity theory of money has a great effect on economy and has several merits. In this theory the relationship may not be proportional but all we know that inflation raises when supply of money increases.

\section{Model Specification, Data \& Methodology}

4.1. Data

For analyzing the model, I selected the time series data of 34 years. This study covered the time period from 1974-2014. In this study, the econometric technologies (ARDA,

Sukkur IBA Journal of Management and Business | Volume 4 No. 1 January - June 2017 @ Sukkur IBA University 
ADF, Correlation Descriptive Analysis and Granger Causality test) are used. This study used secondary data from different sites. The sources of the data collection are following: - SBP (State Bank of Pakistan), PBS (Pakistan Bureau of Statistic), IMF (International Monetary Funds) and handbook of statistics of Pakistan.

\subsection{Model Specification}

In this analysis we used the ADF, ARDL, Descriptive analysis and correlational techniques. The ADF test is used to check the Stationarity of the variables. The ARDL techniques are used to check the long run and run coefficients of the variables. The stability test is used to check the stability of the data.

\section{Equation 1:}

$$
\mathrm{Y}=\mathrm{f}(\mathrm{GDP})
$$

Where

Y=Output,

$\mathrm{GDP}=$ Gross Domestic product.

$$
\mathrm{GDP}=\alpha 0+\beta 1(\mathrm{FDI})+\beta 2(\mathrm{INF})+\beta 3(\mathrm{M} 2)+\beta_{4}(\mathrm{EXR})+\beta_{5}(\mathrm{CPI})+\beta_{6}(\mathrm{TR})+\beta_{7}(\mathrm{PI})+\boldsymbol{\epsilon}
$$

Where

GDP $=$ Gross domestic Product.

FDI= Foreign DIRECT investment.

$\mathrm{INF}=$ inflation.

M2=money supply.

$\mathrm{EXR}=$ exchange rate.

$\mathrm{CPI}=$ consumer price index.

$\mathrm{TR}=$ Total Reserve.

$\mathrm{PI}=\mathrm{PRICE}$ INDICES.

These are variables that affect the capital flow and money supply such as the GDP gross domestic product, total reserves (TR), inflation (INF), consumer price index (CPI), Money supply (M2), foreign direct investment (FDI), and exchange rate (EXR).

In equation (1) Output is dependent variable of GDP but in the 2nd equation GDP is the dependent variable of other variables.

\subsection{Model}

In this diagram the GDP is dependent variable and the independent variables are pi, INF, FDI, CPI, M2 and EXR. The GDP and other variables are connected with each other. Any small change in one variable causes a change in the other variables.

Sukkur IBA Journal of Management and Business | Volume 4 No. 1 January - June 2017 @ Sukkur IBA University 


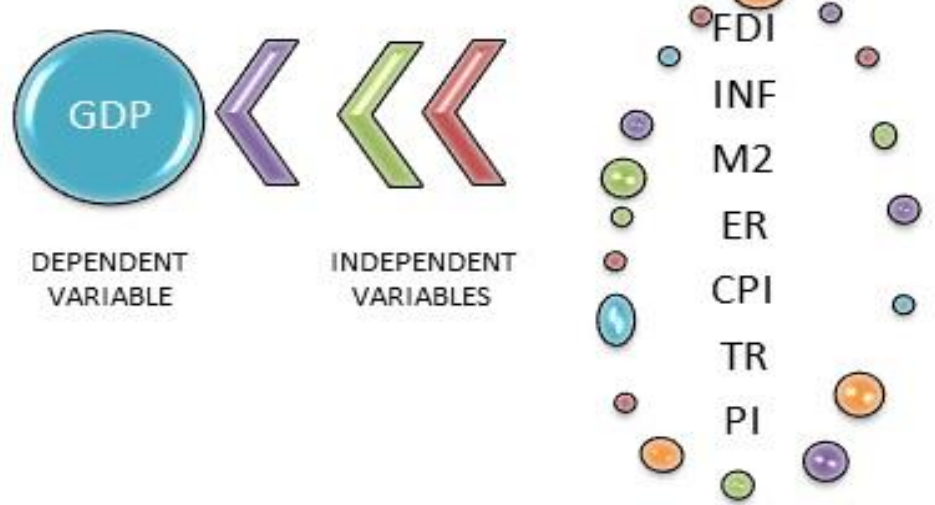

Figure 1: Relationship of the Variables

\subsection{Description of Variables}

\subsubsection{Gross Domestic Product}

The GDP is defined as the economic indicator, the growth which is used to measure the final goods and services which are consumed by the consumer in one year. The GDP is measured by the three ways, One is the income approach second is the expenditure approach and the last one is the product approach. In the product approach, we used to measures the GDP by adding all the income of the factors of the production and then we find out the final value. In the expenditure method we have to calculate the total expenditure which is used by the government for the welfare of the economy.

$$
\mathbf{Y}=\mathbf{C}+\mathbf{I}+\mathbf{G}+(\mathbf{X}-\mathbf{M})
$$

These are the components of the GDP in which the $\mathrm{C}$ is the consumption, $\mathrm{Y}$ is the total output, $\mathrm{I}$ is the investment and the $\mathrm{X}$ is the exports and the $\mathrm{M}$ is the imports.

\subsubsection{Foreign Direct Investment}

There are strong relationships between the Foreign Direct Investment (FDI) and the economic growth. With the help of the FDI the large amount of the FDI is needed in the country for increasing the economic growth. To increase the economic growth by $7 \%$ to $8 \%$, we have to increase the FDI with the investment of the 35 to 40 of GDP. National saving has to be decreased to $10 \%$. The FDI have to meet the gap between the investment and the saving. The government has to produce the opportunities for the foreign investors. FDI defined as foreign direct investment is the investment in a business by an investor from the country for which the foreign investor has control over the company purchased.

\subsubsection{Inflation}

In economy the inflation is referred to increase in the price level. Inflation badly affects the economy growth. Inflation is defined as the sustained rate at which the general price

Sukkur IBA Journal of Management and Business | Volume 4 No. 1 January - June 2017 @ Sukkur IBA University 
level of the goods and services is increased and the purchasing power of the currency is decreased. The standard definition of the inflation is the percentage change in the value of the whole sales price index on the years on year's basis. It effectively measured the change in the prices of the goods and services in years. Inflation means that your money won't buy as much goods as you would yesterday.

Inflation has worst impact on the consumers. Due to inflation the consumers are unable to purchase the necessities of life. The inflation rate of $2 \%$ to $3 \%$ is not bad because at this low inflation rate the consumers purchase the goods and borrow more at this low level of inflation. The interest rate is slow at this low level of the inflation so the people borrow more at this low level of the inflation. The central bank tries to control the inflation at this low level and decrease the deflation.

\subsubsection{Money Supply}

Money supply is the most important indicator of the economy. There is strong relationship between the supply of the money and the prices of the goods. When the supply of the money is increased then the price of the goods is decreased. Federal reserves are the most important determinants of the money supply. Federal serves affect the money supply by altering the component of the money supply as the bank and the debits. Money supply is defined as the group of the safe assets that the household and the businesses used to make the payment or to hold for the short term investment. Total amount of the money assets in the economy is called the money supply. The central bank of the economy measures the supply of the money.

\subsubsection{Exchange Rate}

Exchange rate is the most important element in which we have to determine the economic health of the economy. With the help of economic exchange rate the economy gains stability. The exchange rate is defined as the price of one currency in the term of another currency. There are two types of the exchange rate. One is the fixed and the other is the floating. The fixed exchange rate is measured by the central bank while the floating exchange rate is determined by the mechanism of the market of demand and supply. Values of the currencies relative to one another is called the exchange rate.

\subsubsection{Consumer Price Index}

CPI is used as the economic indicator which is used to estimate the accurate level of the inflation in economy and to use in the value fixation such as the pension etc. CPI is defined as the A measure of the changes in the purchasing the power of the currency and the rate of inflation. The CPI expresses the current prices of the baskets of the goods and services in the terms of prices during the same period in the previous year to show the effect of inflation on purchasing power. CPI is also known as the ECONOMIC and lagging indicator in economy. The CPI is assumed to measure the inflation. Certain categories of the consumption are made by dividing the consumption items. Then the aggregate change in the prices of the goods is measured by the CPI. It can also measure

Sukkur IBA Journal of Management and Business | Volume 4 No. 1 January - June 2017 @ Sukkur IBA University 
cost of living. The inflation is also measured by the proportional change in the index. It gives the amount of the inflationary pressure, increase in the price of the goods and services. CPI is used as the indicators of the change in the prices of the consumers goods while the change in the prices or the money is also be measured by the CPI and the CPI is useful in that situation because it indicates the cost of living.

\subsubsection{Total Reserves}

A reserve means total assets or the total cash in the bank. The total reserves are also the most important indicator of the economy. The economic growth depends on the total reserves that the country has for the better welfare of the economy. The strength of the country is referred to the total reserves of the country. The total reserves make the country more powerful than the others. The sum of all the deposit that the depository initiation such as bank, building society credit union, finance company, insurance company, is allowed to take as the part of the legal requirements. It include on cash, vault, cash in transaction to or from the bank and the current reserves account with the central bank.

\subsubsection{Price Indices}

Price indices are also known as the price indexes and they are referred to as the average prices of the goods and services in a different time period and the different regions. The prices indices are defined as the percentage number that shows the extent to which the price of the goods and services has changed over the time period as compared with the price with the certain years taken as standard. A price index $r$ indices normally average of the prices of the goods and services for the given period or region during the given time interval. The Price index is used to measures the price changes in a particular period of the time to show how the prices of the goods and services are changed according to the change in the quantity and quality of the goods is changed.

Table 1: Unit of Measurement

\begin{tabular}{llll}
\hline Variable & Unit of measurement & Expected sign & Sources \\
\hline GDP & Million dollar & + & PBS \\
FDI & Trillion & + & SBP \\
INF & Million dollar & - & PBS \\
M2 & Million dollar & - & PBS \\
ER & $2010=100$ & + & PBS \\
CPI & $2010=100$ & + & WB \\
TR & Million dollar & + & HBS \\
PI & $2010=100$ & - & WDI \\
\hline
\end{tabular}

Sukkur IBA Journal of Management and Business | Volume 4 No. 1 January - June 2017 @ Sukkur IBA University 


\subsection{Procedure of Estimation}

In estimation process, there are different steps concerned. Estimation process is done with the help of software E-Views 9.5. The analysis used the time series data to approximation of its time series properties firstly apply descriptive and correlation methods on the data. Than check Stationarity of variables with the help of E-views. The estimation process guides to make a decision about the precise methods to be used in the analysis. The next step of estimation of process is (Bound test) to search out whether the long-run association between relating variables exists or not. After that short-run and long-run coefficients will be calculated.

\subsubsection{Stationarity}

It is significant in our judgment to check the stationary consequence of data. Stationary influence in the model arises when the mean and variance of the model are the same (constant) and non-stationary of variable needs the state of non-constant mean and variance. The spurious regression issue may infect the time series data. The spurious regression problem can be avoided by checking the data stationary, that data is stationary or not.

\subsubsection{Unit root test}

This test is implemented to scan the stationary temperament of our associated variables. If the coefficients which are approximate have spurious regression then these coefficients will not have the assumption of BLUE (best linear unbiased estimate). To get away from this dilemma of spurious regression the ADF (augmented dickey fuller) test developed by dickey and fuller is used. They formulated this progression to check the stationary circumstance and then f-version that assembled the lagged value of dependent variable to control the dilemma of autocorrelation in residual term.

\subsubsection{Co-Integration}

Co-integration refers that there is a long run association present between the variables which are non-stationary at level I (0). There are various co-integration methods to analyses the long term connection among variables. Some famous methods of cointegration are Engle-Granger (1987) and Johansen and Jeselius methods. EngleGranger is two stepped residual base method and modern ARDL method now-a-days.

\subsubsection{Auto Regressive Distribution Analysis}

Pesaran, Shin, and Smith (2001), represented the ARDL performance to check the long run and short run relation along with the variables. But only one condition can be estimated through ARDL method. Moreover ARDL is helpful when sample size is small (Narayan, 2004). Johansen and Engle Granger are thought not appropriate to use if sample size is small. When the integration of variable of order zero $\mathrm{I}(0)$ or $\mathrm{I}(1)$ then ARDL is preferred and if there is a mixture of stationary effect of variables at level and first difference then ARDL is also used. Pre testing of variables are required by Johansen co-integration method. This paper also uses ARDL technique which assists

Sukkur IBA Journal of Management and Business | Volume 4 No. 1 January - June 2017 @ Sukkur IBA University 
us to prefer suitable method of estimation further. Wald test is then used as a next step to check the long-term relationship between variables relation exists or not and in the end calculation of short and long run coefficients will be done.

Due to verification of ARDL scheme which is to be implemented at small samples, this study uses ARDL method. If model have dummy variables then to analyze cointegration ARDL is used. ARDL would not show authentic results when variables are integrated of order I(2). Hence in this case ARDL is not used. ARDL performance has two phases; first phase used F. statistics to make sure the long run relation in the model. In next phase the coefficients of long and short run affiliation are checked and include the conclusion application of ARDL system.

\subsubsection{Stability Test}

The stability test of the short run and the long run is explained with the help of the stability test such as the CUSUM test and CUSUM square test. In the CUSUM test the blue lines must be in between the two red lines show the correctness and stability of the test. 4.2.1. Model Specification.

The following equation is estimated to scrutinize the short-run association between following ARDL:

$\Delta$ GDPt $=\mathrm{a} 0+\mathrm{a} 1 \sum \mathrm{kj}=1 \Delta$ GDPt $\mathrm{j}+\mathrm{a} 2 \sum \mathrm{kj}=0 \Delta$ FDIt $\mathrm{j}+\mathrm{a} 3 \sum \mathrm{kj}=0 \Delta \mathrm{INFt}-\mathrm{j}+$ $\mathrm{a} 4 \sum \mathrm{kj}=0 \Delta \mathrm{M} 2 \mathrm{t}-\mathrm{j}+\mathrm{a} 5 \sum \mathrm{kj}=0 \Delta \mathrm{ERt}-\mathrm{j}+\mathrm{a} 6 \sum \mathrm{kj}=0 \Delta \mathrm{CPIt}-\mathrm{j}+\mathrm{a} 7 \sum \mathrm{kj}=0 \Delta \mathrm{TRt}-\mathrm{j}+\mathrm{a} 8 \sum \mathrm{kj}=0 \Delta$ PIt$\mathrm{j}+{ }^{\delta} 1 \mathrm{GDPt}-1+{ }^{\delta}$ FDIt- $1+{ }^{\delta} 3 \mathrm{INFt}-1+{ }^{\delta} 4 \mathrm{M} 2 \mathrm{t}-1+{ }^{\delta} 5 \mathrm{ERt}-1+{ }^{\delta} 6 \mathrm{CPIt}-1+{ }^{\delta} 7 \mathrm{TRt}-1+{ }^{\delta} 8$ PIt $1+\varepsilon 1 \mathrm{t}$

The $2^{\text {nd }}$ step involves the long-run projection relationship between consecutively variables. The following equation is showing the evaluation of long-run model:

GDPt $=\mathrm{a} 0+\sum \mathrm{ki}=0 \theta 1 \mathrm{JGDPt}-\mathrm{j}+\sum \mathrm{ki}=0 \mathrm{a} 1 \mathrm{j}$ FDIt $-\mathrm{j}+\sum \mathrm{ki}=0 \mathrm{a} 2 \mathrm{jINFt}-\mathrm{j}+\sum \mathrm{ki}=0 \mathrm{a} 3 \mathrm{jM} 2 \mathrm{t}-\mathrm{j}$

$+\sum \mathrm{ki}=0 \mathrm{a} 4 \mathrm{j}$ ERt-j $+\sum \mathrm{ki}=0 \mathrm{a} 5 \mathrm{jCPIt}-\mathrm{j}+\sum \mathrm{ki}=0 \mathrm{a} 6 \mathrm{jTRt}-\mathrm{j}+\sum \mathrm{ki}=0 \mathrm{a} 7 \mathrm{jPIt}-\mathrm{j}+\varepsilon \mathrm{t}$

The ARDL technique for the Error Correction (ECM) or short-run illustrated as:

$\Delta$ GDPt $=\mathrm{a} 0+\sum \mathrm{kj}=1 \theta 1 \mathrm{jGDPt}-\mathrm{j}+\sum \mathrm{kj}=0 \mathrm{a} 1 \mathrm{j} \Delta$ FDIt-j $+\sum \mathrm{kj}=0 \mathrm{a} 2 \mathrm{j} \Delta \mathrm{INFt}-\mathrm{j}+$ $\sum \mathrm{kj}=0 \mathrm{a} 3 \mathrm{j} \Delta \mathrm{M} 2 \mathrm{t}-\mathrm{j}+\sum \mathrm{kj}=0 \mathrm{a} 4 \mathrm{j} \Delta \mathrm{ERt}-\mathrm{j}+\sum \mathrm{kj}=0 \mathrm{a} 5 \mathrm{j} \Delta \mathrm{CPIt}-\mathrm{j}+\sum \mathrm{kj}=0 \mathrm{a} 6 \mathrm{j} \Delta \mathrm{CPIt}-$ $\mathrm{j}+\sum \mathrm{kj}=0 \mathrm{a} 7 \mathrm{j} \Delta \mathrm{CPIt}-\mathrm{j}+\prod \mathrm{ECMt}-1+\mu \mathrm{t}$

\section{Descriptive Analysis}

The descriptive analysis is used to check the normality of the data. In this analysis we used the mean, median, maximum, minimum JB value, and the probability value for the normality of the data. 


\begin{tabular}{llllll}
\multicolumn{5}{c}{ Table 2: Descriptive Analysis } \\
\hline Variables & Mean & Skewness & Kurtosis & JB & Prob. \\
\hline GDP & 9.7039 & 0.769041 & 3.5567 & 4.5709 & 0.1017 \\
FDI & 0.8153 & 2.0746 & 6.9046 & 55.4577 & 0.0000 \\
INF & 9.2469 & 1.5332 & 6.0218 & 31.6646 & 0.0000 \\
M2 & 42.1277 & 0.0661 & 2.4521 & 0.5425 & 0.7624 \\
ER & 38.6748 & 0.6892 & 2.2752 & 4.1437 & 0.1259 \\
CPI & -424.15 & 0.3939 & 2.5685 & 1.3785 & 0.5019 \\
TR & 15.2621 & 0.8373 & 2.5158 & 5.1922 & 0.0745 \\
PI & 6.7231 & 1.3950 & 4.0526 & 15.1910 & 0.0005
\end{tabular}

Values calculated form the E-view 9.5

Table showed that all variables are positively skewed. Gross domestic product, money supply, exchange rate, consumer price index are normally distributed and foreign direct investment, inflation rate, total reserves, price indices are not normally distributed. Table also shows that GDP, FDI, INF PI are lapto kustic and other variables are messo kurtic.

Table 3: Correlation among Variable

\begin{tabular}{lllllllll}
\hline Variable & GDP & FDI & INF & M2 & ER & CPI & TR & $\begin{array}{l}\text { P } \\
\text { I }\end{array}$ \\
\hline GDP & 1.0000 & & & & & & & \\
FDI & 0.2788 & 1.0000 & & & & & & \\
INF & 0.0073 & -0.4468 & 1.0000 & & & & & \\
M2 & -0.3721 & -0.4496 & 0.5171 & 1.0000 & & & & \\
ER & 0.7821 & 0.6887 & -0.1776 & -0.3136 & 1.000 & & & \\
CPI & -0.1988 & -0.6306 & 0.4279 & 0.1688 & -0.6475 & 1.000 & & \\
TR & 0.5207 & 0.0929 & 0.1225 & -0.3362 & 0.3428 & -0.0678 & 1.00 & \\
PI & 0.1447 & -0.2591 & 0.5282 & 0.2271 & 0.0447 & 0.5652 & -0.0345 & 1 \\
\hline
\end{tabular}

Source: Authors calculation form the E-views 9.5

In this table we explain the correlation between the variables. We have already proved that all the variables are stationary. In this table the degree of association between the variables is explained. The results are explained in the table where the GDP is positively related to the FDI and the value is 0.2788 shows that there is no multi carnality between the variables. The correlation between the GDP and the INF is positive and the value is 0.00739 showing that there is no multi correlation between the variables. The correlation between the GDP and M2 is -0.37218 showing that there is negatively

Sukkur IBA Journal of Management and Business | Volume 4 No. 1 January - June 2017 @ Sukkur IBA University 
related to the GDP and the values show the absence of the multi carnality. The value of the correlation between the ER and the GDP is indicating that there is no multi co linearity and GDP and ER are positively related. The correlation between the GDP and the TR are 0.52077 indicating that there is no multi co linearity and the GDP AND TR are positively related. The GDP and PI are positively related and the value indicating that there is no multi co linearity. The $1 \%$ change in the GDP can cause the PI to be change $0.14 \%$. Similarly $1 \%$ increase the GDP decrease the money supply by $0.37 \%$. The PI and FDI are negatively correlated and the value indicating that there is no multi co linearity between the PI and FDI. The value is -0.259 . The TR and FDI are positively related and the value indicating that there is no multi-collinearity between the TR and FDI. The exchange rate and FDI are negatively related showing that there is no multi co linearity between the FDI and CPI. M2 and FDI are negatively related and the correlation value is -0.4496 . INF and FDI are negatively related showing that there is no multi-collinearity and the value is -0.4468 . INF and $\mathrm{M} 2$ is positively related and the value is 0.51712 . PI and TR are negatively related and the value is -0.034593 indicating that there is no multi-collinearity.

\subsection{Time Series Analysis}

Time series analysis is used to check the Stationarity of the data by using time series data. In this analysis we used the ADF techniques to check the stationary of the variable and the ARDL is used to check the long run relationship between the variable.

\subsection{Augmented Dicky Fuller Test for Unit root}

The ADF test is used to check the Stationarity of the variables. If the spurious regression is present in the coefficients then we use the ADDF test to remove the spurious problem. This test is developed by the dicky fuller.

Table 4: Augmented Dicky Foller (ADF)

\begin{tabular}{|c|c|c|c|c|c|c|c|}
\hline \multirow{2}{*}{$\begin{array}{l}\text { Vari } \\
\text { able }\end{array}$} & \multicolumn{3}{|c|}{ Level } & \multicolumn{3}{|c|}{ 1st difference } & \multirow{2}{*}{$\begin{array}{l}\text { Concl } \\
\text { usion }\end{array}$} \\
\hline & Intercept & $\mathrm{T} \& \mathrm{I}$ & NONE & Intercept & $\mathrm{T} \& \mathrm{I}$ & NONE & \\
\hline GDP & $-5.096 * *$ & -5.0157 & -3.6186 & - & - & - & $\mathrm{I}(0)$ \\
\hline FDI & 1.9245 & $-5.4021 * *$ & 3.6328 & - & - & - & $\mathrm{I}(0)$ \\
\hline INF & $-4.6524 * *$ & -4.4960 & -2.6190 & _- & _- & - & $\mathrm{I}(0)$ \\
\hline M2 & - & - & - & $-5.9695 * *$ & -6.0749 & -6.0289 & $\mathrm{I}(1)$ \\
\hline ER & - & - & - & -1.1435 & $-6.3940 * *$ & & $\mathrm{I}(1)$ \\
\hline CPI & - & - & - & $-7.5042 * *$ & -7.4358 & -7.3981 & $\mathrm{I}(1)$ \\
\hline $\mathrm{TR}$ & & & & -6.2813 & $-6.1901 * *$ & -6.3554 & $\mathrm{I}(1)$ \\
\hline PI & _ & _ & _ & $-10.3502 * *$ & -7.5720 & -10.371 & $\mathrm{I}(1)$ \\
\hline
\end{tabular}

Source: Authors calculations (*,**,*** means the stationary at 1\%, 5\% and 10\%)

Sukkur IBA Journal of Management and Business | Volume 4 No. 1 January - June 2017 @ Sukkur IBA University 
In this analysis we used the ADF test to check the Stationarity of the variables. In this paper we used the GDP as the dependent variable and the EXR, FDI, INF, PI, TR, CPI are used the independent variables. Form the table we come to know that the GDP, FDI and the INF are the stationary at the level while the remaining variables such as the, INF, PI, TR, and M2 are stationary at the first difference. We check the stationary on the basic of the $t$ statistics and the probability value. When the probability value is less than $0.05 \%$ then the variable is stationary and the stationary of the variable is proved.

\begin{tabular}{ccccc}
\hline \multicolumn{5}{c}{ Table 5: Leg } \\
\hline$R^{2}$ & Akaike & SEHWAZ & HANNAN & D\&W \\
0.998714 & 1.321136 & 2.183024 & 1.927789 & 2.102208 \\
0.998824 & 1.383086 & 2.340929 & 1.720771 & 2.381721 \\
0.9971770 & 1.999319 & 2.747092 & 2.260312 & 2.051542 \\
\hline
\end{tabular}

Source: Calculated form the E-VIEW 9.5.

In this table we have to use the auto regressive distribution lag which shows the different lags in which set the criteria of akaike and the value of $r$ square, banana, schwas and the Durban Watson are given. These are the two steps of the ARDL in which first of all we check the long run association with the help of bound test. We make the null and alternative hypothesis the null hypothesis is that there is no presence of long run association while the alternative hypothesis is that there is presence of the bound test.

$\mathrm{H} 0$ : there is no long run association.

$\mathrm{H} 1$ : there is long run association.

Table 6: Bound test for Co- integration

\begin{tabular}{ccc}
\hline F STAT & 3.978866 \\
\hline CRITICAL BOND VAUE & LCB & UCB \\
$10 \%$ & 1.92 & 2.89 \\
$5 \%$ & 2.17 & 3.21 \\
\hline
\end{tabular}

Source: critical value is taken from e views 9.5

The table of the bound test indicates that there is a long run association and we reject the null hypothesis and accept the alternative hypothesis.

Table 7: Diagnostic Test

\begin{tabular}{ccc}
\hline TEST STAT & & \\
\hline SERIAL CORRELATION & LAGRANGE MULTIPLIER & $0.2267(.7995)^{*}$ \\
NORMALITY & TEST & $0.4400(.0 .8024)$ \\
HETROSCEDASTICITY & $\begin{array}{c}\text { Ramsey's RESET test } \\
\text { Based on the values of test of } \\
\text { skewness and kurtosis }\end{array}$ & $0.590357(.8543)^{*}$ \\
\hline
\end{tabular}

Sukkur IBA Journal of Management and Business | Volume 4 No. 1 January - June 2017 @ Sukkur IBA University 


\begin{tabular}{ccc}
\hline FUNCTIONAL FORM & $\begin{array}{c}\text { Based on the value of regression } \\
\text { of squared residuals. }\end{array}$ & $2.6859(.0 .0969)^{*}$ \\
\hline Valuescalulated fro
\end{tabular}

Values calculated from the E-VIEW 9.5

The result of the diagnosis test shows the there is no auto correlation, hetrosedasticity in the model. The normality test indicates that the model is normally distributed. The result of the functional form indicates that there is no error in the mode.

\subsection{Estimates of Long Run Coefficients of Model}

\begin{tabular}{ccccc}
\multicolumn{5}{c}{ Table 8: long run Estimation of the Model } \\
\hline Variable & Co-efficient & Probability & Standard Error & t-statistics \\
\hline FDI & 0.5369 & 0.0159 & 0.0240 & 2.6468 \\
INF & -0.000 & 0.9938 & 0.0397 & -0.0078 \\
M2 & -0.143 & 0.0019 & 0.0398 & -3.6014 \\
ER & 0.2896 & 0.000 & 0.0136 & 21.2258 \\
CPI & 1.9003 & 0.000 & 0.0688 & 27.586 \\
TR & -0.5273 & 0.000 & 0.0322 & -16.3365 \\
PI & -0.3883 & 0.000 & 0.0240 & -16.1357 \\
C & 821.25 & 0.000 & 29.449 & 27.8867 \\
\hline
\end{tabular}

Source: table of long run calculated from the e views 9.5

The table shows the long run integration of the model. In this model the dependent variable is the GDP and the EXR is positively related to that of the GDP and pob value shows that it is significant. When the exchange rate is increased then the GDP of the economy is increased and the economic growth is increased. This finding is confirmed with the finding of the Attaché Oberg (2013), Patrick Emu (2013) and OPOKU (2013). They explain the linear relationship between the EXR and GDP.

The FDI is significant and also positively correlated with the GDP. As the foreign investment is increased the foreign earning is increased and the GDP of the economy is also increased with the same trend 0.53 percent increase in the FDI also increases the GDP. The finding of LIM GUECHEANG (2013) and PSHLAJMOOLIO (2013) also match with our findings. There is a positive relationship between the FDI and GDP. The inflation is insignificant and negatively related to the GDP as the inflation in economy is increased which badly affected the Economic growth of the economy. Our finding is confirmed with the findings of (Hashmi et al., 2011; Senhadji, 2000). They explain that there is negative relationship between the INF and the GDP. As the 1\% increases in the government expenditure, it causes the M2 to decrease the $0.14 \%$ and the inflation is decreased by the $0.0003 \%$. 


\begin{tabular}{ccccc}
\multicolumn{5}{c}{ Table 9: short run coefficient estimation } \\
\hline Variable & Co-efficient & Probability & Error & t-statistic \\
\hline$\Delta$ GDP(-4) & 0.0224 & 0.0368 & 0.00999 & 2.2456 \\
$\Delta($ FDI $)$ & 0.2241 & 0.3411 & 0.2295 & 0.9765 \\
$\Delta(\mathrm{INF})$ & -0.0443 & 0.1512 & 0.0296 & -1.495 \\
$\Delta(\mathrm{M} 2)$ & -0.3142 & 0.000 & -7.6572 & -7.657 \\
$\Delta \mathrm{D}(\mathrm{ER})$ & 0.1413 & 0.0009 & 0.0360 & 3.923 \\
$\Delta \mathrm{D}(\mathrm{CPI})$ & 2.1381 & 0.000 & 62.190 & 62.190 \\
$\Delta \mathrm{D}(\mathrm{TR})$ & -0.5944 & 0.000 & -28.818 & -28.183 \\
$\Delta \mathrm{D}(\mathrm{PI})$ & -0.4257 & 0.000 & 0.014 & -29.119 \\
Coint.Eq(-1) & -0.9266 & 0.000 & 0.1653 & -5.6036 \\
\hline
\end{tabular}

The process of the short term coefficient is completed with the co-integration. Its range lies between the 0 and -1 . The correlation between the period $t$ and the period $t-1$ is the error which is explained by the correlation. The value of ECM is 0.92 and is significant. It indicated that the variation in the GDP form the equilibrium level in the current period is adjusted by the $92.66 \%$ in the next year. The remaining variables such as $\mathrm{D}$ (INF), $\mathrm{D}(\mathrm{PI}), \mathrm{D}(\mathrm{M} 2)$ and the $\mathrm{D}(\mathrm{ER})$ have the same results as in the long run co integration. DINF and DPI are negatively related to the GDP and is insignificant. DFDI shows the positive relationship and significant with the GDP in the short run. As the 1\% increase in the government expenditure on the Monterey policies then the inflation is covered by the $0.41 \%$.

\subsection{Stability Test}

The stability test of the short run and the long run is explained with the help of the stability test such as the CUSUM test and CUSUM square test. In the CUSUM test the blue lines must be in between the two re lines show the correctness and stability of the test.

Cusum Test:

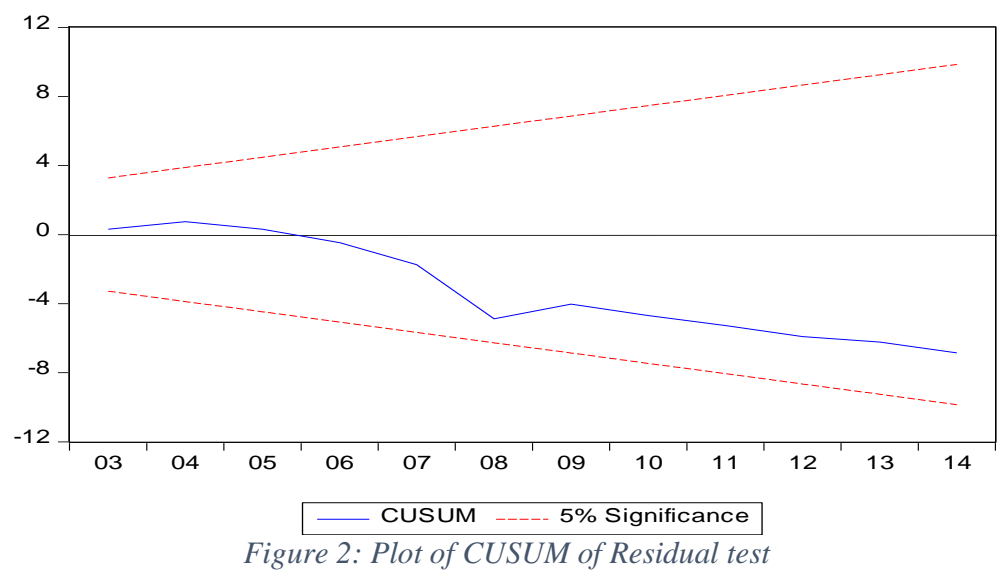

Sukkur IBA Journal of Management and Business | Volume 4 No. 1 January - June 2017 @ Sukkur IBA University 


\section{CUSUMSEQURE TEST:}

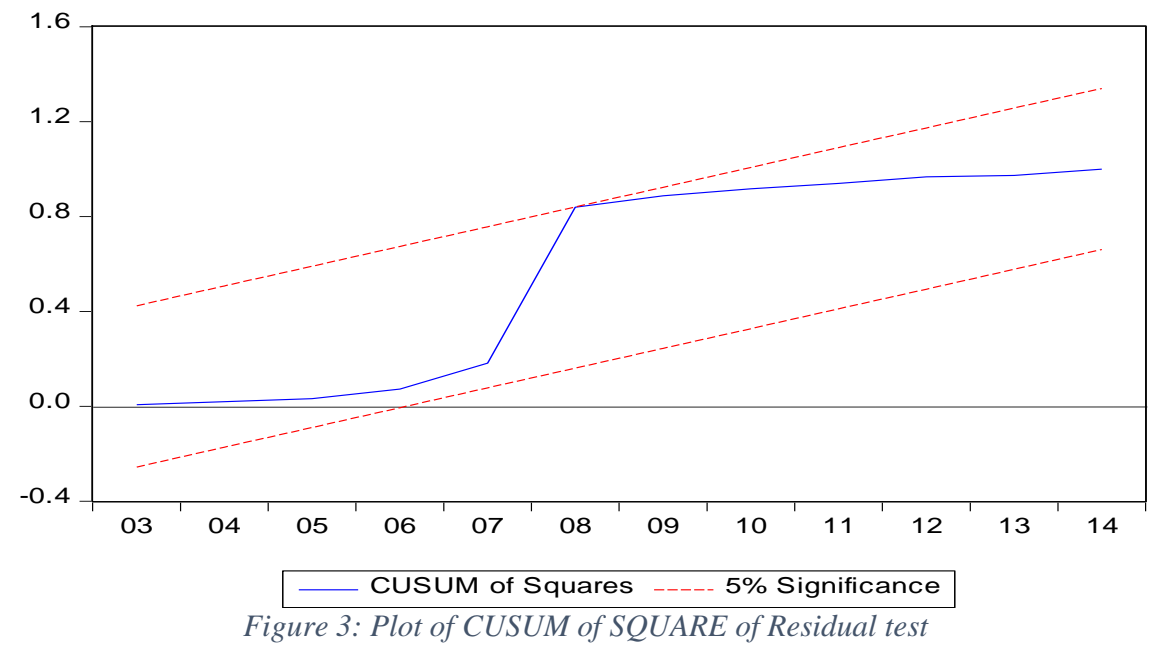

\section{Conclusion}

In this analysis we have to investigate the capital flow and the money supply: and the degree of sterilization in Pakistan. The basic objective of this study is to have to solve the problem of the economy which is rising by the greater supply of the money. In this paper we have to use the secondary data ranging from the 1974 to 2014. The variables are Gross domestic product, inflation, price indices, money supply, foreign direct investment, consumer price index and the total reserves used in this paper. The techniques which are used to prove the model area the descriptive analysis, correlation test, ADF and ARDL test used to check the stationary of the variables. All the variables are stationary some are stationary at level and the some at stationary at 1 st difference. The ADRL model indicates that there is a long run association between the variables. The auto regressive model explains that the M2, Pi and INF are negatively related with the GDP and the other variables area positively related to the GDP. The correlation value of the EXR rate is -0.9988 showing that if the exchange rate is decreased then the GDP is also affected and the economy growth is also affected by this change. It is suggested that the monetary policy should be improved to increase the exchange rate and then economy growth trend is increased. The descriptive analysis is indicating that all the variables are normally distributed. Some are the leptokurtic and the some area the mesa kurtosis.

We used the Freidman model of money supply which explains the relationship of the money supply, output and the inflation. Our finding is confirmed with the Friedman model indicating that when the inflation is increased then the economy is badly affected by the inflation and the output is affected. The finding of this study is that there is high correlation between the money supply, inflation and EXR.

Sukkur IBA Journal of Management and Business | Volume 4 No. 1 January - June 2017 @ Sukkur IBA University 


\section{Policy Recommendation}

The government should improve the monetary policy. In this way there is no more inflation in economy. Government should increase the expenditure on the foreign direct investment in this way the foreign earing is increased and the economy growth is increasing. With the help OS the foreign direct investment the employment of the host country is also to be increased.

\section{References}

Alberola, E., \& Serena, J. M. (2007). Global financial integration, monetary policy and reserve accumulation: Assessing the limits in emerging economies.

Bordo, M., \& Filardo, A. (2005). Deflation and monetary policy in a historical perspective: Remembering the past or being condemned to repeat it? Economic Policy, 20(44), 800-844.

Demyanyk, Y., \& Hasan, I. (2010). Financial crises and bank failures: A review of prediction methods. Omega, 38(5), 315-324.

Farhi, E., Gourinchas, P.-O., \& Rey, H. (2011). Reforming the international monetary system: CEPR.

Fry-McKibbin, R. A., \& Wanaguru, S. (2013). Currency intervention: A case study of an emerging market. Journal of International Money and Finance, 37, 25-47.

Hashmi, M. S., Xu, C., Khan, M. M., Bashir, M., \& Ghazanfar, F. (2011). Monetary Policy Reaction Function and Sterilization of Capital Inflows: An Analysis of Asian Countries. Asian Social Science, 7(9), 19.

Hyder, Z., \& Mahboob, A. (2006). Equilibrium real effective exchange rate and exchange rate misalignment in Pakistan. SBP Research Bulletin, 2(1).

Jegajeevan, S. (2015). Validity of the Monetary Model of the Exchange Rate: Empirical Evidence from Sri Lanka. Staff Studies, 42(1).

Kaufman, G. G., Mote, L. R., \& Rosenblum, H. (1984). Consequences of deregulation for commercial banking. The Journal of Finance, 39(3), 789-803.

Khan, M. A. (2008). Long-run and short-run dynamics of foreign reserves and domestic credit in Pakistan. International Journal of Applied Econometrics and Quantitative Studies, 5(1), 61-84.

Lagner, T., \& Knyphausen-Aufseß, D. (2012). Rating agencies as gatekeepers to the capital market: Practical implications of 40 years of research. Financial Markets, Institutions \& Instruments, 21(3), 157-202.

Narayan, P. K. (2004). Fiji's tourism demand: the ARDL approach to cointegration. Tourism Economics, 10(2), 193-206.

Obstfeld, M. (1998). The global capital market: benefactor or menace? : National bureau of economic research.

Ocampo, J. A. (2003). Capital account and counter-cyclical prudential regulations in developing countries. From Capital Surges to Drought: Seeking Stability for Emerging Markets. Palgrave Macmillan, London, 217-244.

Sukkur IBA Journal of Management and Business | Volume 4 No. 1 January - June 2017 @ Sukkur IBA University 
Pesaran, M. H., Shin, Y., \& Smith, R. J. (2001). Bounds testing approaches to the analysis of level relationships. Journal of applied econometrics, 16(3), 289326.

Qayyum, A., \& Khan, M. A. (2003). Capital flows and money supply: the degree of sterilisation in Pakistan. The Pakistan Development Review, 975-985.

Rashid, A., \& Husain, F. (2013). Capital inflows, inflation, and the exchange rate volatility: an investigation for linear and nonlinear causal linkages. The Pakistan Development Review, 183-206.

Senhadji, A. (2000). Sources of economic growth: An extensive growth accounting exercise. IMF staff papers, 47(1), 129-157.

Ullah, S., Haider, S. Z., \& Azim, P. (2012). Impact of exchange rate volatility on foreign direct investment: A case study of Pakistan. Pakistan economic and social review, 121-138.

Sukkur IBA Journal of Management and Business | Volume 4 No. 1 January - June 2017 @ Sukkur IBA University 